\title{
Experiences of a battalion medical officer in the retreat to Dunkirk: IV
}

\author{
Richard Doll
}

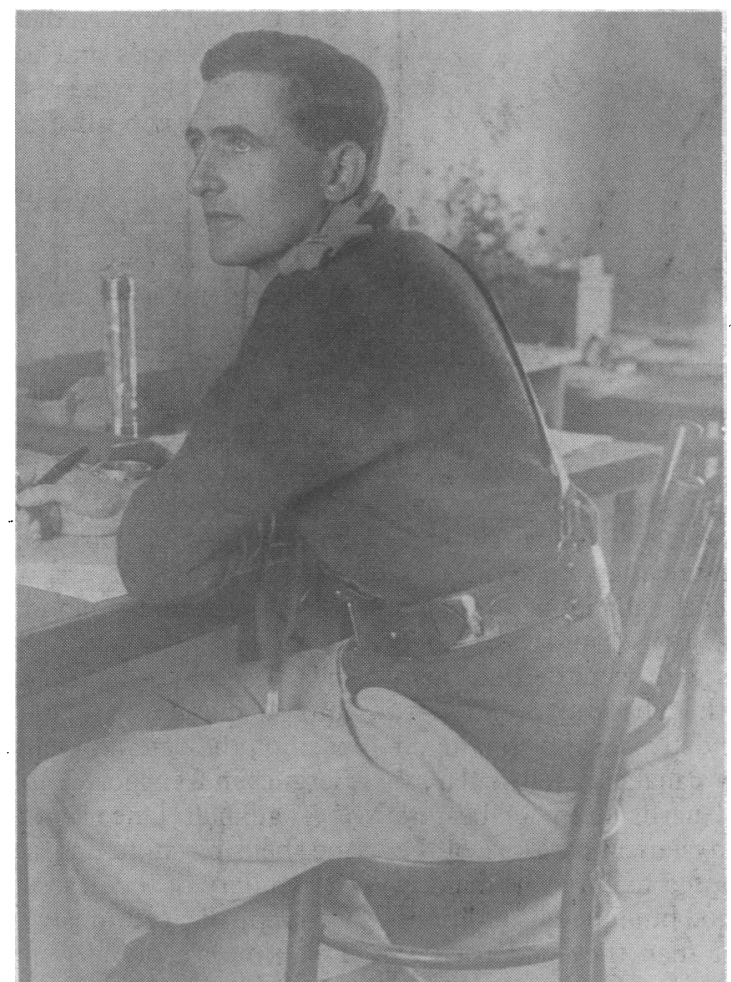

Richard Doll, Cairo, 1943

\section{Wednesday 29 May}

By now I had woken up again and was full of energy. The one overriding consideration in my mind was to get to our destination before dawn, before the bombers could find us and bomb us on the march. I soon found myself with Willy Anderson in the advance party. No one seemed to know what road we were on or in what direction we were going-and, moreover, very few seemed to care.

About 0230 we checked, and Willy and I pushed on to try and pick up the track again. I went through a period of anxiety in the next half hour which I hope never to repeat; but at last my energy was rewarded and in the next village I found a signpost pointing to Hondschoote. My opinion was vindicated and I returned joyously to the men, who by now were convinced we were irremediably lost.

We pushed on at a good speed, but owing to taking a wrong turn (I was no longer in the lead, having been ignominiously reminded that the place of the medical officer was not with the advance guard) we did not arrive at Hondschoote till nearly 0600 , having had to climb over the barbed wire which had been put up during the winter along the Franco-Belgian frontier. From Hondschoote we soon came to the canal which was to form the boundary of the defended area and rejoiced to see troops taking up defensive positions on the far side. We passed through them and on (very slowly) for two miles to the next village. By now the battalion was a tragic sight; the men, who had marched and dug continuously for 48 hours, straggled in twos and threes over several miles. As we neared the village the adjutant stopped for a moment, and, marshalling the nearest troops, fell them in in threes and besought them to make a last effort and arrive in style. So successful was this that as we entered the village (perhaps 50 of us) we heard someone say, "That's the first lot of men I've seen keeping their ranks today."

Here we were met by the quartermaster and the second in command. There was tea and biscuits for the men and coffee for the officers. I have never been more grateful for anything in my life than that coffee. We stayed for three hours, during which time I lay almost lifeless on a stone floor, and then formed up and started off again. We marched for four miles through long lines of abandoned transport. Slowly the fields were being flooded and the rising water and the wrecked cars created a scene of desolation that is impossible to imagine. French troops wandered aimlessly throughout, stopping to search each lorry that was not already obviously plundered. At times the road was impassable with abandoned traffic, and we had to work our way round through the flooded fields. Meanwhile, odd planes hovered overhead, occasionally honouring us with a burst of machinegun fire, but for the most part frightening us with the thought of the reports they must be sending back. We passed through Gyvelde and on to the canal in front of Bray. Here we stopped and, to my horror, began to take up defensive positions for the umpteenth time. The Gordons (who had at last arrived) were now on our left, and we and they were to man the canal, the last line of defence two miles from the sea, in case the Germans should break through the front line along the bank of the canal behind Hondschoote. We chose a farmhouse some 500 yards behind the canal as battalion headquarters, and I established my regimental aid post in a detached brick building just in front of it. The whole country in all directions was dotted with soldiers, French and British. It was impossible to tell who was defending the line and who was resting on the way through. Abandoned trucks littered the road and the fields, here and there providing a display of fireworks where an ammunition truck was on fire or a petrol dump had been set alight. Twice during the afternoon the bombers came over in large numbers, but they left us alone and concentrated on Dunkirk and the beaches behind us. If by chance a plane did come low down it was greeted by such a volley of smallarms fire that it soon took to the clouds again. While wandering round trying to find out what was going on I was lucky enough to find a medical officer who was with a unit which was to be embarked that night. Somehow he had still got his truck with him - a Vauxhall van filled with his personal goods and medical equipment. He was good enough to give it all to me so that, what with this and the stretchers I picked up from the deserted ambulances, I was able to equip my aid post better than since we were first on the Dyle. Having had some food, I turned in about 2000 and went to sleep. This was the first sleep I had had for 60 hours, and I have never enjoyed anything more in my life.
Richard Doll, FRS, honorary member and emeritus professor 


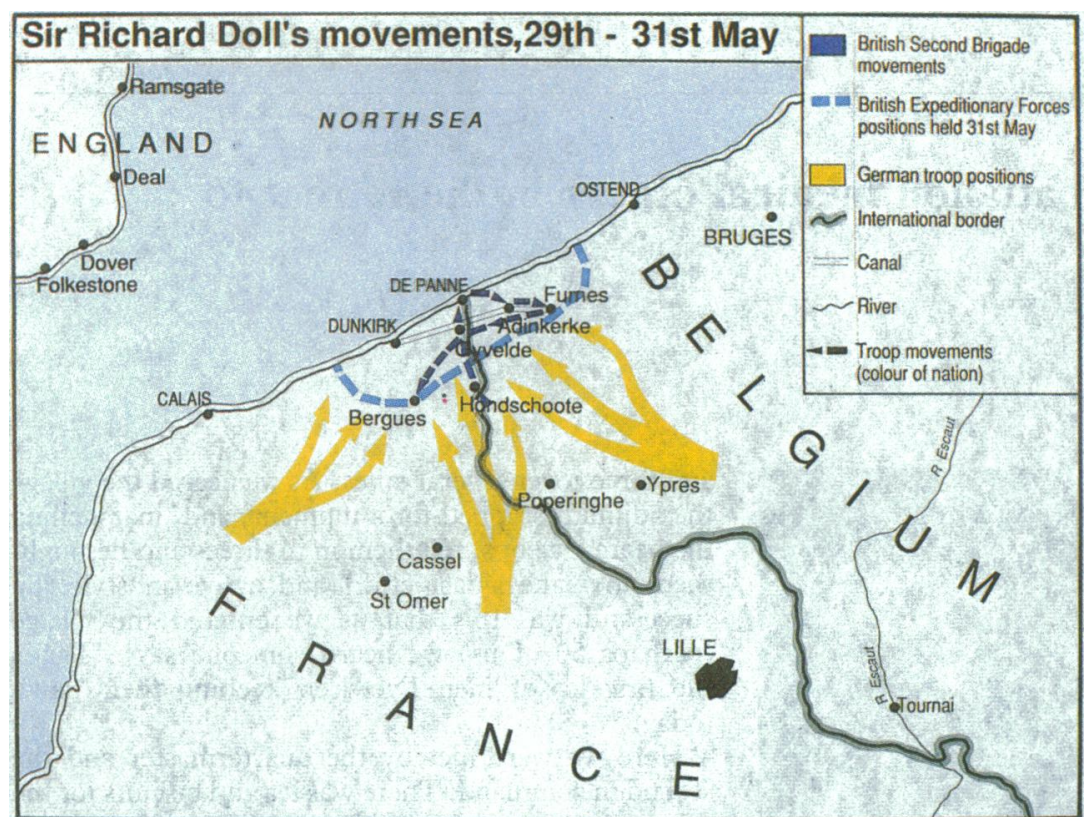

Note: British Second Brigade movements refer to movements of 2nd Brigade of Ist Division

\section{Thursday 30 May}

I awoke refreshed and, having breakfasted, I wandered out on to the road to see if I could find any casualties. The road inland over the canal through Gyvelde was in an even worse state than it had been the day before. In order to get past the abandoned vehicles I had to wander out behind the houses into the flooded fields. I found several trucks with wounded on them and collected parties to carry them back to my aid post, to which several other wounded had also gravitated from the forward defended canal. In particular, I picked up four Coldstream Guards stretcher bearers who had carried a man with hysterical paralysis of the legs back four miles. I attempted to cure this man by the "stand up and walk" method but failed. Conditions were less ideal for treatment than they had been at Poperinghe as he was able to see cars still moving along the less blocked roads; eventually I had to put him into an ambulance. I satisfied myself that there were no more wounded on the road as far forward as the regimental aid post of the King's Shropshire Light Infantry, in front of Gyvelde, where Baxter had similarly been collecting wounded. By midday each of us had about 20 in our posts, and I now had to find out how to get rid of them. Pechey, an Ordnance man attached to the battalion, had found a motorbicycle and he offered to try to get me down to the beach on it. By pushing in between trucks and from time to time lifting it over others we got through the first half mile and then had a more or less clear run to the sea. On the promenade we found first division headquarters and saw the first signs that anybody was trying to straighten out the mess.

A major told me that I had two options, to send the men either direct to the quay at Dunkirk or to the 12th casualty clearing station, which was still functioning at De Panne. In the house next to headquarters Jenkins was striving to create a field ambulance out of his regimental aid post. He had collected several ambulances and with the help of Hebbert from the 21st Antitank Regiment was treating and evacuating some 30 to 40 patients. One of these gave me a Michelin map of Belgium, which I would subsequently hardly have got on without. Getting on to the back of the motorbicycle, Pechey took me off along the sands for four miles till we reached De Panne. I soon found the hospital and persuaded the colonel to lend me two ambulances on the understanding that I would immediately return them to him after having evacuated my patients. I came back rather a long way round through Furnes and Adinkerke and subsequently learnt that for a considerable distance we had driven along the front line.

At Adinkerke I saw a field ambulance actually working; I have since heard that at least two others were about somewhere but the great majority (including the three in our division) had either gone or were sitting waiting on the beach. In so doing the first division ambulances were only following the example of the assistant director of medical services, who had left on the Monday, washing his hands of the entire affair.

On arriving back at my regimental aid post I found that Carney (my medical orderly) had already got some ambulances and had evacuated my patients to Rosendael, where the rest of the 12th casualty clearing station had established a hospital, about a mile from the docks.

During the previous night 50 of the battalion had been allowed to go down to the beach and embark so that we were expecting to get off at any moment. However, we were to be disappointed, for we were suddenly ordered to go forward to Bergues where, we were told, the Germans had broken through. The adjutant borrowed four lorries from an artillery regiment close by and sent off $\mathrm{D}$ company to hold the enemy on the canal immediately in front of Dunkirk while the rest set off the seven miles on foot with the idea of passing through $\mathrm{D}$ company and counter attacking on their arrival. Meanwhile, he set about collecting more functioning transport, which was dispatched as it was found to pick up the marching men. In an hour he had succeeded in transforming us into a mobile battalion, and from D company's position the battalion moved forward the four miles to Bergues in transport. I followed behind the column in my Vauxhall. Once as we were passing a gun position the shells began falling around us, and we rushed into the scullery of the nearest house. After a few minutes we crept out cautiously to be met by another salvo. This time we literally tumbled into the cellar of the next house but not before Carney received a small piece of metal in his arm. We spent an amusing 10 minutes talking to the occupants of the house, who, like most of the civilians I met, seemed to be taking the bombardment stoically and unconcernedly.

From there we turned off the road parallel to the sea and went inland towards Bergues. The battalion was advancing cautiously stage by stage, but the only military activity we saw, apart from the periodic bombing of Dunkirk behind us, was the Lincolns and the 9th Foresters digging themselves in on the banks of the canal along which we were passing. By 1800 we reached the canal in front of Bergues and crossing over we entered the town by the Ypres gate.

Bergues is an old country town built on the side of a hill at the junction of three canals, about five miles directly inland from Dunkirk. It is entirely surrounded by great earth ramparts and pierced by four gates. Here it was evident that a battle had already been fought. Many of the houses were destroyed, and smoke was still appearing from several ruins in the central square. Fortunately, the houses all had large cellars and I soon found a yard where I could hide my car, from which opened a maze of cellars. The yard beyond was piled with tins of food of all sorts, enough to feed a battalion for several weeks, so I went off in search of the adjutant to spread the good news. I then learnt how we had been tricked. The town was still occupied by a mixed force of troops, Royal Army Service Corps, Royal Army Ordnance Corps, and odd detachments of infantry, commanded by Brigadier Usher. There had been no question of the Germans breaking through, and it was obvious that a false report had been sent in to get us to take over the town. The officers in control had taken 


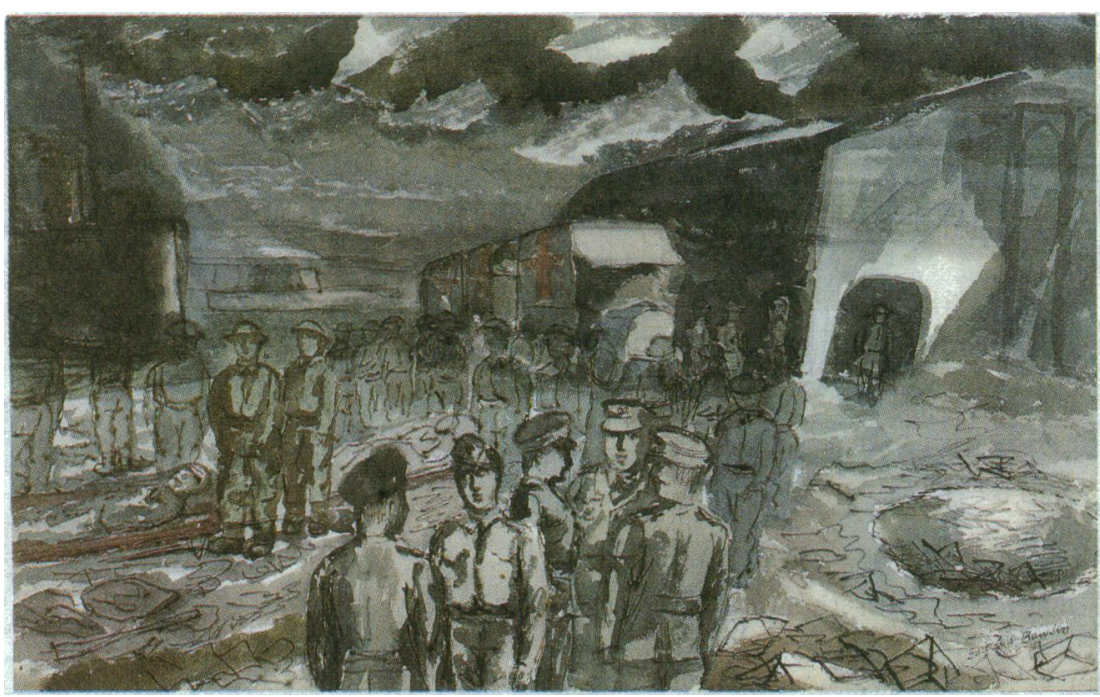

"Dunkerque. Embarkation of wounded, May 1940” by Edward Bawden. Reproduced by courtesy of the trustees, Imperial War Museum

over a large and beautifully furnished house, and when we descended into the cellar where they were messing, we found them feasting off roast chicken and champagne. On seeing us, they immediately said, "Oh, the relieving troops" and gave orders to leave at 0200 the next morning before we had got over our surprise at seeing them.

When I last knew Usher he had been lieutenant colonel in command of the 1st Gordons who had been in the same brigade with us at the beginning of the war. He had been promoted to colonel and put in charge of a camp at the base. He had subsequently acquired another pip and had some command on the lines of communication. When the Germans poured up the coast and taken us in the rear it had fallen on him to defend St Omer (so I believe) with such troops as were available. He had then withdrawn to Bergues, where undoubtedly they were bombed and shelled quite heavily and where he now succeeded in getting us to take over from him.

I learnt that further up the road a hospital with 20 beds was already established in a large cellar, and, going there, I found two medical officers from the fifth casualty clearing station (asleep in bed) with some half dozen Royal Army Medical Corps orderlies under a Sergeant Harris, a man notable for his aristocratic voice, who had instructed me in gas at the field ambulance training camp the previous July. The sergeant was quite drunk on rum (of which he had found two kegs) and proceeded to get me tight while giving me, Carney and Stiles (my batman) a large meal of stew and bread and butter. I naturally moved my provisional regimental aid post to this cellar (that is, drove my car from one shelter to another) and returned to the mess, the walls of which contained several gross of Bordeaux and Burgundy.

I returned to the underground hospital at 2300 and fell into bed; happy and as near drunk as I had been during the campaign.

\section{Friday 31 May}

A beautiful, quiet day. I woke up to find that the Royal Army Medical Corps personnel whom we had "relieved" had left at 0200 , leaving behind them two wounded Frenchmen in my cellar, one of whom had died in the night and the other was in great pain with a compound fracture of the leg. The cellar stank foully, and the first thing I did was to open wide all available ventilators, collect four stretcher bearers, and get the whole place cleaned out and washed. By midday, after a thorough airing, it had become bearable again. Meanwhile, I had found a French surgeon who was attached to a company of French soldiers who were also holding the town. He had a complete hospital in the cellars of what must have been a fair sized hospital in peace time, where, with the help of the nuns, he was treating French civilians and soldiers alike. I offered to give him any help he required, but he seemed to be coping as adequately as possible, infinitely better than I could have. I transferred the wounded Frenchman to him while some of the dead man's comrades came to collect his belongings. We had hoped to bury him, but eventually he got left with several others in the backyard behind my cellar. The next day the French hospital received a direct hit, and when I last saw the surgeon, he was valiantly trying to carry on in a small cellar opposite mine, under the handicap of the loss of all his instruments.

I must have slept very heavily in that cellar, for when I turned up at the mess for breakfast I was told that the colonel had looked in on me on his morning inspection at 0430 and, poking me in the back, had said, "Wake up, you fat pig of a stretcher bearer," before he realised whom he was speaking to. However, as I remembered nothing of the incident I bore no malice.

I spent the day exploring the town and raiding various shops. A grocer's shop gave us such delicacies as tinned asparagus, Camembert cheeses, and sweet biscuits, while I made up my now extensive medical stores from a chemist's shop. A young nurse was filling several baskets with the most exotic drugs and hundreds of dressings. We piled all these into a lorry and drove her up to the top of the hill, whence we helped her carry them down to a hospital she had stocked 100 feet deep in the ramparts. Here, in a series of tunnels, the majority of the civilian population were living, supporting themselves by periodic raids into the town. The nurse had three young mothers in her small room 20 feet by 12 feet, two of whom had but recently given birth, while the third was expecting at any moment. She found a bottle of wine and we drank to our futures in the most carefree and happy manner. Our party was broken up by a raid by some dozen planes - a thing which always seemed to occur when I left my post for any length of time.

I came down from the hill and went for tea to the barracks where a company of West Kents were living. This company had been on the extreme left wing of the British front when we were on the Escaut, and had got left behind when an order was given for precipitate withdrawal. They had wandered about for a week among the Belgian Army trying to find us and had eventually got attached to Usher's force where, being leapt upon with joy as fighting troops, they had been given an outpost to hold a mile in front of the town. When we took them over they were utterly desperate, believing that no one had any interest in them and that they would certainly get left behind in the embarkation. We also took over some 60 Warwicks, a platoon of Welsh Guards, and 60 or 70 odd men from various regiments. All these the adjutant collected together, formed into companies, and absorbed into our battalion (which now by the loss of wounded and chiefly by stragglers was reduced to some 500 men). The Welsh Guards were made into policemen, and all took new heart on realising that they were no longer forgotten men; most were kept in reserve for the next two days and all left Dunkirk with us.

About 2000 I went into the mess for dinner. We sat down to take a cocktail on the ground floor when two shells landed close behind us. We had been arguing as to whether to begin dinner or not, but these shells settled it; I went down to the cellar, and the others soon followed me, and dinner was served. Throughout the meal shells continued to fall and it was apparent that we were in for a heavy bombardment. We broke up soon afterwards to get as much sleep as we could.

The fifth and final article will appear next week 